\title{
ESTIMATIVE OF GENETIC PARAMETERS IN PROGENY TEST OF PINUS \\ CARIBAEA MORELET VAR. HONDURENSIS BARRET \& GOLFARI BY QUANTITATIVE TRAITS AND MICROSATELLITE MARKERS $\left({ }^{1}\right)$
}

\author{
EVANDRO VAGNER TAMBARUSSI $\left({ }^{2 *}\right)$; ALEXANDRE MAGNO SEBBENN $\left({ }^{3}\right)$; \\ MÁRIO LUIZ TEIXEIRA DE MORAES ( $\left.{ }^{4}\right)$; LÉO ZIMBACK $\left({ }^{5}\right)$; \\ EDWIN CAMACHO PALOMINO $\left({ }^{6}\right)$; EDSON SEIZO MORI $\left({ }^{6}\right)$
}

\begin{abstract}
The aims of this work were to estimate the coefficient of relatedness within families and the genetic parameters for growth related traits in a progeny test from an open-pollinated variety of Pinus caribaea Morelet hondurensis Barret \& Golfari, established in Mato Grosso do Sul State, Brazil. The experimental design was the triple $10 \times 10$ lattice, with 96 families, three replicates, and ten plants per plot. Fourteen years after planting, the trial was measured for the following traits: total height, diameter at breast height $(\mathrm{DBH})$, and true volume. The estimation of coefficients of relatedness within family from microsatellite loci indicated that families are true half-sibs $\left(\hat{r}_{x y}=0253\right)$. Thus, the additive genetic variance $\left(\sigma_{\mathrm{A}}^{2}\right)$ can be estimated assuming that the genetic variance among progenies $\left(\sigma_{\mathrm{p}}^{2}\right)$ accounts for $1 / 4$ of additive genetic variance $\left(\hat{\sigma}_{\mathrm{A}}^{2}=4 \hat{\sigma}_{\mathrm{p}}^{2}\right)$. The estimative of heritability coefficients at individual level $\left(h_{i}^{2}\right)$ was relatively high $(0.28$ for $\mathrm{DBH}$ and 0.44 for height). The heritability coefficient considering the average families $\left(\mathrm{h}_{\mathrm{n}}^{2}\right)$ was also high, ranging among the traits from 0.50 to 0.58 . These results suggest that the population can be improved by both massal and among families selection. Additionally, the estimated genetic gains with sequential selection among and within families were high (ranging from $8.92 \%$ for height to $37.56 \%$ for volume), demonstrating that this method of selection can generate high genetic improvement.
\end{abstract}

Key words: Pinus; tree breeding; genetic parameters; microsatellite markers; coefficient of relatedness.

$\left({ }^{1}\right)$ Received for publication in October 9, 2008 and accepted in August 27, 2009.

$\left({ }^{2}\right)$ Escola Superior de Agricultura "Luiz de Queiroz", ESALQ/USP, Caixa Postal 9, 13418-900 Piracicaba (SP). E-mail: evtambarussi@yahoo.com.br (*) Corresponding author. Bolsista FAPESP.

$\left({ }^{3}\right)$ Instituto Florestal, Estação Experimental de Tupi, Caixa Postal 339, 13400-970 Piracicaba (SP), Brasil. E-mail: alexandresebbenn@yahoo.com.br

$\left({ }^{4}\right)$ Departamento de Fitotecnia, FEIS/UNESP, Avenida Brasil 56, 15385-000 Ilha Solteira (SP), Brasil

$\left(^{5}\right)$ Instituto Florestal de Avaré, Caixa Postal 237, 18603-970 Botucatu (SP). E-mail: nativas@fca.unesp.br,

$\left(^{6}\right)$ Departamento de Produção Vegetal - Agricultura e Melhoramento Vegetal da Faculdade de Ciências Agronômicas, FCA/ UNESP, Caixa Postal-237, 18603-970 Botucatu (SP). E-mail: edwin@fca.unesp.br 


\title{
RESUMO \\ ESTIMATIVAS DE PARÂMETROS GENÉTICOS EM TESTE DE PROGÊNIES DE PINUS CARIBAEA VAR. HONDURENSIS POR CARACTERES QUANTITATIVOS E MARCADORES MICROSSATÉLITES
}

\begin{abstract}
Os objetivos deste trabalho foram estimar o coeficiente de parentesco dentro de famílias e os parâmetros genéticos e fenotípicos para os caracteres de crescimento (altura, diâmetro a altura do peito e volume) em um teste de progênies de polinização aberta de Pinus caribaea Morelet var. hondurensis Barret \& Golfari, implantado no Estado de Mato Grosso do Sul, Brasil. O teste foi implantado em látice $10 \times 10$ triplo, com 96 famílias, três repetições e dez plantas por parcela. Quatorze anos após o plantio foram mensurados os caracteres altura total, DAP e volume das árvores. A estimativa dos coeficientes de parentesco dentro das progênies foi calculada por locos microssatélites os quais revelaram que as famílias são de meio-irmãos $\left(\hat{r}_{\mathrm{x}}=0253\right)$. Assim, a variância genética aditiva $\left(\sigma_{\mathrm{A}}^{2}\right)$ pode ser estimada, assumindo que a variância genética entre progênies $\left(\sigma_{\mathrm{p}}^{2}\right)$ estima $1 / 4$ da variância genética aditiva $\left(\hat{\sigma}_{\mathrm{A}}^{2}=4 \hat{\sigma}_{\mathrm{p}}^{2}\right)$. As estimativas do coeficiente de herdabilidade em nível de planta $\left(\mathrm{h}_{\dot{2}}^{2}\right)$ foram relativamente elevadas $\left(0,28\right.$ para DAP e 0,44 para altura). A herdabilidade em nível de média de famílias $\left(h_{n}^{2}\right)$ foi também elevada variando entre os caracteres de 0,50 , a 0,58 . Estes resultados sugerem que a população pode ser melhorada por seleção massal e seleção entre famílias. Adicionalmente, as estimativas dos ganhos genéticos com seleção entre e dentro famílias foram elevados (variando de 8,92\% para altura a 37,56\% para volume), demonstrando que este esquema de seleção pode trazer grande progresso genético.
\end{abstract}

Palavras-chave: Pinus, melhoramento florestal, microssatélites, coeficiente de parentesco.

\section{INTRODUCTION}

Pinus caribaea var. hondurensis occurs naturally in Central America: Belize, Guatemala, Honduras, Nicaragua, Mexico (Perry, 1991) and El Salvador (CAMCORE, 1996). This species can grow in elevations up to $1000 \mathrm{~m}$, but it generally grows between the sea level and $500 \mathrm{~m}$ (Hodge and DvoraK, 2001). The trees can reach heights of $30 \mathrm{~m}$ (RICHARDSON, 1998).

The increase in the genetic relatedness among sibs caused by the mating system affects the estimative of genetic parameters for quantitative traits due the increase in both genetic covariance between sibs and genetic variance among families. As a result, the effectiveness of selection within families may be reduced (RITLAND 1989). Some Pines species present a mixed mating system. Thus, open pollinated families have mixture of different degrees of inbreeding and relatedness (RITLAND, 1989; SEBbenN, 2002). If the mating system involves mixtures of outcrossing, selfing and correlated mating, open pollinated families will contain mixtures of half-sibs, self-sibs, full-sibs and self-halfsibs (Ritland, 1989; SebBenn, 2002). Consequently, the relatedness within families will be higher than expected in half-sib families (0.25) and the additive genetic variance $\left(\sigma_{\AA}^{2}\right)$ in progeny tests cannot be estimated assuming that the genetic variance among families $\left(\sigma_{\mathrm{p}}^{2}\right)$ estimate $1 / 4$ of additive genetic variance $\left(\hat{\sigma}_{\hat{\alpha}}^{2}=4 \hat{\sigma}_{\mathfrak{r}}^{2}\right)$. Assuming that open pollinated families from mixed mating system species are true, half-sibs will produce overestimates in the addictive genetic variance and, thus in the heritability and genetic gains (Ritland, 1989; Sebbenn et al., 2002; Sebbenn,
2003). Thus, it is very important to know the average of relatedness within families. The coefficient of relatedness within families can be estimated using genetic markers and samples from progeny arrays, and those estimations used for to analyse the additive genetic variance, $\hat{\sigma}_{\mathrm{A}}^{2}=\hat{\sigma}_{\mathrm{p}}^{2} / \hat{\mathrm{r}}_{\mathrm{x}}$.

Many models have been proposed for the estimation of genetic parameters of quantitative traits in sort of mixed mating system. The model proposed by RitLAND (1989) is the most complete because it considers that open-pollinated families are composed by mixture of self-sibs, half-sib, full-sibs, and selfhalf-sibs (SEBBENN, 2002). Other models consider that open-pollinated families are compound only by mixtures of self-sibs and half-sibs, excluding the fullsibs.

Microsatellites constitute molecular markers with large polymorphic availability (ECHT et al., 1996; Ferreira and Grattapaglia, 1998). Molecular markers based on microsatellite amplification are excellent tools for monitoring genetic diversity and understanding mating systems of populations submitted to selection in tree breeding programs. For example, FURLAN et at. (2007) utilized microsatellite loci to quantify genetic diversity in different stages of a $P$. caribaea var. hondurensis breeding program. In an advanced generation of breeding, the authors observed loss of low-frequency alleles as well as an increasing in the frequency of the most common alleles. Additionally, ten potential pairwise mating opportunities to obtain intra-specific hybrid vigor in descendant generations were detected. 
To select superior trees within breeding programs, it is important to understand the relationships among heritability and the correlation between ages and traits of economic interest, as well as seed-origin and the mating system of the species. Therefore, the aims of this study were: i) to estimate the coefficient of relatedness within families from mating system parameters using microsatellite loci; ii) to estimate genetic parameters for growing traits in a $P$. caribaea var. hondurensis progeny test; iii) to adjust the heritability coefficient as a function of the relatedness existing within families.

\section{MATERIALS AND METHODS}

\section{Experimental site and design}

The study was carried out in an openpollinated $P$. caribaea var. hondurensis progeny test established in 1986 in Selvíria, Mato Grosso do Sul $\left(20^{\circ} 20^{\prime} \mathrm{S}, 51^{\circ} 23^{\prime} \mathrm{W}\right.$, altitude $\left.370 \mathrm{~m}\right)$. The families were originated from a clonal seed orchard named "Genetic Conservation Center and Tropical Pines ImprovementGCCTPI," located in Aracruz, Espírito Santo (1949'S, $40^{\circ} 16^{\prime} \mathrm{W}$, altitude $50 \mathrm{~m}$ ). The trial was established in $10 \times 10$ triple lattice, containing 96 families from GCCTPI and four families from commercial stands (using as control), ten plants per plot and three replications. In 2002, the trial was submitted to a selective logging by removing four trees $(40 \%)$ of each plot. Quantitative traits were measured in 2004, 14 years after planting. The studied traits were total height (distance along the axis of the stem of the tree from the ground to the uppermost point), dbh (diameter at breast height), and real volume. The real volume of trees was calculated by the expression $\mathrm{V}=\frac{\pi}{4} .(\mathrm{dbh})^{2} . h .$, where is the quotient of stem form $q=\frac{d 1 / 2 H}{d b h} ;$ where $d 1 / 2 H$ is diameter in half of height of a tree and dbh is diameter at breast height).

\section{Microsatellite analysis}

To estimate mating system parameters using microsatellite loci, leaves were collected from six trees of each family. The DNA extraction was based on Doyle and Doyle (1987) protocol, modified by Grattapaglia and Sederoff (1994). The extracted DNA was quantified in a GeneQuantPro spectrophotometer and its concentration was adjusted for $5 \mathrm{ng} / \mu \mathrm{L}$ for using in PCR reactions. For Pinus species, there are already primers which can be used within the same taxon or for species with genetic affinity (FERREIRA and Grattapaglia, 1998; BYrne et al., 1996). Thus, primers were transferred from other Pinus species to P. caribaea var. hondurensis. In this project, 20 primers pairs were tested: RPS12, RPS20, RPS25b, RPS84 (Pinus strobus, Echt et al., 1999), PSM2, PSM34 (Pinus sylvestris, Kostia ET al., 1995), PR4.6, PR9.3 (Pinus radiata, SMITH and DeveY, 1994), APC3, APC9, (Pinus contorta var. latifolia, Hicks et al., 1998), APC11, APC13 (Pinus contorta var. latifolia, Hicks et al., 1998), RPS150, RPS160 (Pinus strobus, Еснт et al., 1999), PtTX2037, PtTX2034, PtTX3011, PtTX3029 (Pinus taeda, ElsiK et al., 2001), RPTest01, and RPTest09 (Pinus taeda, EchT and Burns, 1999). However, only six primer pairs were efficiently transferred and displayed polymorphism for the studied species (PtTX2037, PtTX3029, RPTest01, RPTest09, PR4.6, and PSM2).

The amplification reactions were made in the thermocycler Programmable Thermal Controller - 100 (MJ Research Inc.), using the following thermal profile: $5 \mathrm{~min}$. at $94^{\circ} \mathrm{C}$, followed by 32 cycles of 30 seconds at $94^{\circ} \mathrm{C}, 45$ seconds of annealing at temperatures of $57^{\circ} \mathrm{C}$ for primers RPTest 01, RPTest 09, PtTX 3029, and PSM 2, and for primers PR 4.6 and PtTX $2037,60^{\circ} \mathrm{C}$ and $48^{\circ} \mathrm{C}$, respectively. This was followed by $1 \mathrm{~min}$ at $72^{\circ} \mathrm{C}$, and $10 \mathrm{~min}$ at $72^{\circ} \mathrm{C}$ for the final extension. The total volume of the mixture was $17 \mu \mathrm{L}$, with $1.7 \mu \mathrm{L}$ of buffer $10 \mathrm{X}$ PCR Buffer, 1 unit of taq DNA polymerase, $3 \mu \mathrm{L}$ of DNA $(5 \mathrm{ng} / \mu \mathrm{l}), 0.6 \mu \mathrm{L}$ of each primer $(10 \mu \mathrm{M}), 1.5$ $\mu \mathrm{L}$ of solution of dNTP $(0.5 \mathrm{mM})$ and $0.85 \mu \mathrm{L}$ of $\mathrm{MgCl}_{2}$ $(50 \mathrm{mM})$. The amplification products were subjected to electrophoresis in Metaphor (FMC Bioproducts) agarose gel $3 \%$; the coloration made in ethidium bromide $2 \%$ ( $2 \mathrm{~mL}$ in $1.5 \mathrm{~L}$ of water for 1 hour). The bands were visualized in ultraviolet light and photographed.

\section{Analysis of variance and components of variance}

The variance analysis for each measured trait was computed at the individual level, according to the lattice scheme proposed by COCHRAN and COx (1981), using the following statistical model: $\mathrm{Y}_{\mathrm{ijqu}}=\mathrm{m}+\mathrm{r}_{\mathrm{j}}+$

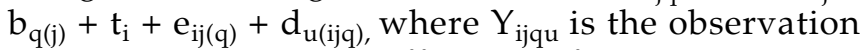
in the u-th tree (plant's effect), i-th family, q-th block, and $j$-th replicate; $m$ is the general mean; $r_{j}$ is the effect of the $j$-th replicate, with $j=1,2, \ldots, r ; b_{q(j)}$ is the effect of the q-th block within replicate $j$, with $q=1,2, \ldots, b$; $t_{i}$ is the effect of the $i$-th family, with $i=1,2, \ldots, t ; e_{i j(q)}$ is the intra-block error effect (error among plots), and; $\mathrm{d}_{\mathrm{u}(\mathrm{ijq})}$ is the error effect within plots.

These analyses were carried out using the SAS software (SAS, 1999). Since the trial was unbalanced due to an unequal number of surviving trees in the plots, the Restricted Maximum Likelihood (REML) method was used to estimate the variance components. REML and VARCOMP procedures (SAS, 1999) were used in combination for these estimates. 
The estimated components of variance stimated were: $\sigma_{\mathrm{p}}^{2}=$ genetic variance among families; = variance of the interaction of family by replicate; $\sigma_{\mathrm{w}}^{2}=$ phenotypic variance within families.

\section{Estimates of genetic parameters}

The estimates of genetic and phenotypic parameters for the measured quantitative traits were based on VENCOVSKY and BARRIGA (1992). The additive genetic variance among families was estimated using the mixed mating model and correlated mating model. These models assume that plants of the same family can be generated for mixtures of self-fertilization, random mating, and correlated mating because families can contain different levels of relatedness as self-sibs (sb), half-sib (hs), full-sibs (fs), and self-halfsibs (shs). The additive genetic variance $\left(\sigma_{\AA}^{2}\right)$ was calculated by: $\hat{\sigma}_{\mathrm{A}}^{2}=\hat{\sigma}_{\mathrm{p}}^{2} / \hat{\mathrm{r}}_{\mathrm{x}}$, where $\sigma_{\mathrm{p}}^{2}$ is the genetic variance among families and $\left(r_{x y}\right)$ is the coefficient of relatedness within families, estimated from the mating system parameter by the following expression: $\hat{r}_{\mathrm{sy}}=025\left(1+\hat{\mathrm{F}}_{\mathrm{p}}\right)\left[4 \hat{\mathrm{s}}+\left(\mathrm{t}_{\mathrm{m}}^{2}+\hat{r}_{s} \hat{\hat{n}_{\mathrm{n}}} \hat{\mathrm{s}}\right)\left(1+\hat{r}_{\mathrm{p}}\right)\right]$ (RITLAND, 1989), where $F_{p}$ is the inbreeding coefficient in the parental population $S$, is the selfing rate $\left(\hat{s}=1-\hat{t}_{n}\right), t_{m}$ is the multilocus outcrossing rate, $r_{s}$ is the self-correlation (or the likelihood of two randomly sampling sibs within a family are self-sibs), and $r_{p(m)}$ is the multilocus paternity correlations (or the likelihood that two randomly selected offspring from a single family are full-sibs). The mating system parameters were estimated using mixed-mating model (RITLAND and JAIN, 1981) and correlated mating model, implemented in the program MLTR (RITLAND, 2002).

The heritability coefficients at individual plants level $\left(h_{i}^{2}\right)$, average among families $\left(h_{m}^{2}\right)$, and within families $\left(h_{w}^{2}\right)$, were estimated using the following expressions:

$$
\hat{h_{1}^{2}}=\frac{\hat{\sigma}_{\AA}^{2}}{\hat{\sigma}_{\mathrm{p}}^{2}+\hat{\sigma}_{\mathrm{e}}^{2}+\hat{\sigma}_{w}^{2}}, \quad \hat{h}_{\mathrm{m}}^{2}=\frac{\hat{\sigma}_{\mathrm{p}}^{2}}{\hat{\sigma}_{\mathrm{p}}^{2}+\frac{\hat{\sigma}_{\mathrm{e}}^{2}}{\mathrm{~J}}+\frac{\hat{\sigma}_{\mathrm{w}}^{2}}{\overline{\mathrm{n} J}}}, \quad \hat{h_{w}^{2}}=\frac{\left(1-\hat{r}_{\mathrm{s}}\right) \hat{\sigma}_{\mathrm{A}}^{2}}{\hat{\sigma}_{w}^{2}},
$$

where $\sigma_{e}^{2}$ is the experimental error; $\sigma_{v}^{2}$ is the phenotypic variance within families; $\bar{n}$ is the harmonic average number of plants within plots.

The following variation coefficients were estimated: within families: $\mathrm{CV}_{\mathrm{w}}\left(\frac{0}{0}\right)=\frac{\sqrt{\hat{\sigma}_{w}^{2}} 100}{\overline{\mathrm{m}}}$; environmental: $\mathrm{CV}_{\mathrm{e}}(\%)=\frac{\sqrt{\hat{\sigma}_{\mathrm{e}}^{2}} 100}{\overline{\mathrm{m}}}$; genetic among families: $\mathrm{CV}_{\mathrm{g}}\left(\frac{\%}{0}\right)=\frac{\sqrt{\hat{\sigma}_{\mathrm{p}}^{2}} 100}{\overline{\mathrm{m}}}$; phenotypic at plant level: $\mathrm{CV}_{\mathrm{F}}\left(\frac{\partial}{\partial}\right)=\frac{\sqrt{\hat{\sigma}_{\mathrm{F}}^{2}} 100}{-}$; phenotypic at average family level: $\left.\mathrm{Cv}_{\overline{\mathrm{F}}} \tilde{F}_{\sigma}\right)=\frac{\sqrt{\hat{\sigma}_{\bar{F}}^{2}} 100}{\mathrm{~m}}$; experimental: $\mathrm{CV}\left(\frac{5}{0}\right)=\frac{\sqrt{\mathrm{MS}_{\text {resicial }}} 100}{\mathrm{~m}}$, where $(\mathrm{MS}=$ mean square $)$.
The selection ratio ( $\hat{b}$ ) and correlation due to the common environment of the plot $\left(\hat{C}^{2}\right)$ were estimated as: $\hat{b}=\frac{\mathrm{CV}_{\mathrm{g}}}{\mathrm{CV}}$ and

\section{Correlation between traits}

The correlation between traits was calculated based on FALCONER (1981). The analysis of covariance between families $\left(\operatorname{cov}_{\mathrm{P}(x, y)}\right)$ was estimated by:

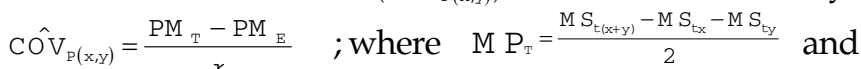
$M P_{z}=\frac{M S_{e(x+y)}-M S_{e x}^{Y}-M S_{e y}}{2}$ are the mean product of families and environments, respectively. The addictive genetic covariance was calculated between $x$ and $y$ traits $\left(\operatorname{cov}_{\mathrm{A}(x, y)}\right)$ by: $\operatorname{có}_{\mathrm{A}(x, y)}=4 \mathrm{CO}^{\prime} \mathrm{V}_{\mathrm{p}(x, y)}$, and genetic correlations between traits were estimated using the equation: $r_{A(x, y)}=\frac{\operatorname{CO}^{\prime} V_{A(x, y)}}{\sqrt{\hat{\sigma}_{A X}^{2} \hat{\sigma}_{A Y}^{2}}}$, where $\operatorname{COV}_{A(x, y)}$ is the genetic covariance between $\mathrm{x}$ and $\mathrm{y}$ traits, and $\sigma_{\mathrm{px}}^{2}$ and $\sigma_{\mathrm{py}}^{2}$ are the genetic variances among families for $x$ and $y$ traits, respectively. Genetic covariances were estimated from the analysis of covariance using SAS software (SAS, 1999).

\section{Selection gains}

To estimate the expected gains from selection, the following expression was used: $\mathrm{SG}_{\mathrm{x}}=\frac{\mathrm{k}_{1}(1 / 4) \hat{\sigma}_{\mathrm{A}}^{2}}{\sqrt{\hat{\sigma}_{\overline{\mathrm{F}}}^{2}}}+\frac{\mathrm{k}_{2}(3 / 4) \hat{\sigma}_{\mathrm{A}}^{2}}{\sqrt{\hat{\sigma}_{\mathrm{w}}^{2}}}$; where $\sigma_{\overline{\mathrm{F}}}^{2}$ is the average of phenotypic variance among families, is the phenotypic variance within families), $\sigma_{\mathrm{A}}^{2}$ is the additive genetic variance, $\mathrm{k}_{1}$ is the differential of selection in standard deviation unit among families $\left(30 \%\right.$, with $\left.k_{1}=1.16\right)$ and $k_{2}$ is the differential of selection in standard deviation unit within families $\left(10 \%\right.$, with $\left.\mathrm{k}_{12}=1.54\right)$.

\section{RESULTS AND DISCUSSION}

\section{Variance analysis}

The present experiment showed a high survival index $(90.4 \%)$, suggesting a good adaptation of the species to the experimental site (Selvíria). The efficiency of the lattice for dbh and height traits was high (Table 1) and more than $110 \%$, the limit established by Miranda Filho (1978) for the total adjustment of treatments and the mean squares to the effective error, justifying the use of this design for the analysis of variance of the traits. Furthermore, the coefficient of experimental variation $(\mathrm{CV})$ was relatively low for height $(4.7 \%)$ and $\mathrm{dbh}(7.2 \%)$, and median for volume $(17.7 \%)$, indicating that reliable estimates can be obtained from the variance analyses. 
Higher CV value for volume is expected, when comparing to $\mathrm{dbh}$ and height parameters, as volume is estimated from these two other variables, combining the experimental errors of both of them.

Table 1. Results of the variance analysis for growth traits of $P$. caribaea var. hondurensis at 14 years of age, at Selvíria, State of Mato Grosso do Sul, Brazil

\begin{tabular}{lcccc}
\hline Trait & Means & CV & F (prog.) & E.LT $\left(^{1}\right)$ \\
\hline & prog. & $\%$ & & $\%$ \\
Height $(\mathrm{m})$ & 23.20 & 4.75 & $1.96^{* *}$ & 50.68 \\
dbh $(\mathrm{cm})$ & 25.04 & 7.16 & $1.92^{* *}$ & 116.55 \\
Volume $\left(\mathrm{m}^{3}\right)$ & 0.7499 & 17.75 & $2.30^{* *}$ & 142.84 \\
\hline
\end{tabular}

$\left({ }^{1}\right)$ Efficiency of the Lattice; ${ }^{*} p<0.05 ;{ }^{* *} p<0.01$

Significant differences among families were detected for all studied traits (Table 1), suggesting the possibility of population improvement by selection of the best families. This finding also showed that even though the trial was submitted to previous selective logging, substantial genetic variation remained for selection.

\section{Growth Traits}

Regarding growing of $P$. caribaea var. hondurensis, an annual average increment (AAI) of $1.66 \mathrm{~m}$ for height and $1.88 \mathrm{~cm}$ for dbh was observed. The AAI for height was higher than other tree species evaluated. Hodge et al. (2001) found a height of 12.62 $\mathrm{m}$ at eight years of age and a AAI of $1.58 \mathrm{~m}$ for the species in Aracruz, State of Espírito Santo, Brazil. BARRICHELO et al. (1978) reported the average height of $10.35 \mathrm{~m}$ at nine years of age, which corresponds to a AAI of only $1.15 \mathrm{~m}$. The highest height growth was observed by Lima (1990), who found a AAI of $1.70 \mathrm{~m}$ for Pinus caribaea var. hondurensis in Camanducaia, State of Minas Gerais, Brazil. The height was also lower than the height detected for $P$. tecunumanii at seven years of age, with a height of $12.42 \mathrm{~m}$, corresponding to a AAI of $1.77 \mathrm{~m}$ in São Simão, State of São Paulo, Brazil (SEBbenn et al., 1995).

Regarding growing in dbh, the value observed for AAI was superior to that found by FREITAS et al. (2005) for the species at 32 years of age $(\mathrm{dbh}=31.45$ $\mathrm{cm}, \mathrm{AAI}=0.98 \mathrm{~cm})$, growing in Bebedouro, State of São Paulo, Brazil, BARRICHELO et al. (1978) at nine years of age $(\mathrm{dbh}=13.35 \mathrm{~cm}, \mathrm{AAI}=1.48 \mathrm{~cm})$ and BALLONI et al. (1978) at seven years of age $(\mathrm{dbh}=14.8 \mathrm{~cm}, \mathrm{AAI}=2.11$ $\mathrm{cm}$ ) for the same species, growing in Agudos, State of São Paulo, Brazil. However, the AAI in dbh was inferior to that related by Hodge et al. (2001) in Aracruz (dbh $=17.98 \mathrm{~cm}, \mathrm{AAI}=2.25 \mathrm{~cm}$ ) for the same species and for NiCOLIELO (1984), working with different P. caribaea var. hondurensis provenances in Agudos, State of São Paulo, Brazil, who found growth in dbh ranging from 21.56 to $23.62 \mathrm{~cm}$ at 11 years of age, resulting in AAI ranging from 1.96 to $2.15 \mathrm{~cm}$. These values were 4 to $14 \%$ higher than those showed in the present work.

\section{Estimates of genetic parameters}

The estimates of the coefficient of variation within families $\left(\mathrm{CV}_{\mathrm{w}}\right)$, enviromental $\left(\mathrm{CV}_{\mathrm{e}}\right)$, genetic among families $\left(\mathrm{CV}_{\mathrm{g}}\right)$, phenotypic at plant level $\left(\mathrm{CV}_{\mathrm{F}}\right)$, phenotypic at average level $\left(\mathrm{CV}_{\mathrm{F}}\right)$, and of the selection quotient ${ }_{b}$ ) are presented in Table 2 . Comparing the genetic variations among families, within families, and for environment, the highest values occurred within families, indicating that genetic gains can be exploited by individual phenotypic selection within the best families. Dbh has high genetic and phenotypic variation, showing this trait is easier to select, and higher genetic gains can be obtained by selection. Among the analyzed traits, the volume $(\hat{b}=0.67)$ was the most indicated for selection. However, some difficulties should be considered due the high experimental error associated to this estimate. There are high genetic and phenotypic correlations between dbh and volume in Pinus sp. (SEBbenn et al., 1994; 1995; Zheng et al., 1994; Missio et al., 2004). Thus, the selection for volume can be indirectly carried out, using the $\mathrm{dbh}$ as the variable for direct selection.

The correlation due to the common environment of the plots (Table 1) was also analyzed. It was verified that the dbh presented $5.9 \%$, height $21.8 \%$, and volume $9.3 \%$. According to ReSENDE (2001), values of lower than $15 \%$ can be considered as adequated. In this case, $15 \%$ of the total phenotypic variation was due to the environmental variation among plots. Thus, only the height parameter did not show a good estimate.

The relatedness coefficient $\left(r_{x y}\right)$ within families was estimated using data from mating system parameters calculated from eight microsatellite loci. The estimated coefficient of relatedness $\left(\hat{r}_{x y}=0.253\right)$ was near the expected value in half-sib families $(0.25)$. This result was unexpected, since MATHESON et al. (1989) detected multilocus outcrossing rates of 0.89 and 0.92 in populations of $P$. caribaea var. hondurensis from Mountain Paine Ridge and Melinda, both from Belize. However, considering that the species had a mixed mating system (MATHESON et al., 1989), the present result could be associated to inbreeding depression and selection against homozygote trees from the selffertilization and mating among relatives between the phases of fertilization and the evaluation of the offspring in the trial (12 years of age). 
Table 2. Estimates of the coefficient of variation $(C V)$, coefficient of variation within families $\left(C_{\mathrm{w}}\right)$; environmental $\left(\mathrm{CV}_{\mathrm{e}}\right)$; genetic among families $\left(\mathrm{CV}_{\mathrm{g}}\right)$; phenotypic in plant level $\left(\mathrm{CV}_{\mathrm{f}}\right)$; phenotypic in average family level $\left(\mathrm{CV}_{\bar{f}}\right)$; estimate of the correlation due to the common environment of the parcel $\left(C^{2}\right)$ and the quotient of selection (b), for total height, dbh and volume of P. caribaea var. hondurensis at 14 years of age in Selvíria, State of Mato Grosso do Sul, Brazil

\begin{tabular}{|c|c|c|c|c|c|c|c|c|}
\hline \multirow{2}{*}{ Trait } & \multicolumn{8}{|c|}{ Coefficient of variation } \\
\hline & $\mathrm{CV}_{\mathrm{w}}$ & $\mathrm{CV}_{\mathrm{e}}$ & $\mathrm{CV}_{\mathrm{g}}$ & $\mathrm{CV}_{\mathrm{f}}$ & $\mathrm{CV}_{\overline{\mathrm{f}}}$ & $\mathrm{CV}$ & $\hat{b}$ & $\hat{C}^{2}$ \\
\hline & & & & 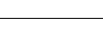 & & & & \\
\hline Height (m) & 6.67 & 3.81 & 2.72 & 8.14 & 3.84 & 4.75 & 0.57 & 0.218 \\
\hline $\mathrm{dbh}(\mathrm{cm})$ & 14.44 & 3.75 & 4.05 & 15.46 & 5.73 & 7.16 & 0.57 & 0.059 \\
\hline Volume $\left(\mathrm{m}^{3}\right)$ & 32.55 & 11.09 & 11.87 & 36.38 & 15.55 & 17.75 & 0.67 & 0.093 \\
\hline
\end{tabular}

Thus, only trees from outcrossing probably survive until 12 years of age, resulting in a very high estimate of outcrossing rate. Therefore, it is possible to assume that the genetic variance among families estimates $1 / 4$ of the additive genetic variance $\left(\sigma_{\mathrm{p}}^{2}=025 \sigma_{\mathrm{A}}^{2}\right)$.

All coefficients heritabilities were relatively high (Table 3 ), suggesting a strong genetic control of the traits at the individual level, among families, and within families. These results suggest that important genetic progress can be achieved using a simple massal selection in the trial, or a combined selection among and within families. Sampaio (2000) found for P. caribaea var. hondurensis from Isla de Guanaja, Honduras and Poptun, Guatemala, heritabilities at the individual level $\left(h_{i}^{2}\right)$ for height, $d b h$, and volume of $0.25,0.25$ and 0.38 , respectively. Within families $\left(h_{w}^{2}\right)$, the authors found values of 0.24 , 0.21 , and 0.37 , respectively, for the same traits. The values observed in this study were higher than those observed by THIS AUTHOR, confirming the promising genetic control of the traits as well as the high potential of the population for selection.

Table 3. Estimates of heritability coefficients at individual level $\left(\hat{h}_{i}^{2}\right)$, average among families $\left(\hat{h}_{m}^{2}\right)$ and within families $\left(\hat{h}_{w}^{2}\right)$ for height, $\mathrm{dbh}$, and volume of $P$. caribaea var. hondurensis at 14 years of age established at Selvíria, State of Mato Grosso do Sul, Brazil

\begin{tabular}{lccc}
\hline \multirow{2}{*}{ Traits } & \multicolumn{3}{c}{ Heritability coefficients } \\
\cline { 2 - 4 } & $\hat{h}_{i}^{2}$ & $\hat{h}_{m}^{2}$ & $\hat{h}_{w}^{2}$ \\
\hline Height $(\mathrm{m})$ & 0.44 & 0.50 & 0.50 \\
dbh $(\mathrm{cm})$ & 0.28 & 0.50 & 0.24 \\
Volume $\left(\mathrm{m}^{3}\right)$ & 0.43 & 0.58 & 0.40 \\
\hline
\end{tabular}

Estimate of genetic and phenotypic correlations among the traits

All estimated genetic and phenotypic correlations between the traits were high and significant and genetic correlations were generally higher than phenotypic correlations (Table 4). This suggests the possibility of indirect selection in a trait with direct selection in another trait. As previously discussed, volume was the indicative trait for selection, but this trait was associated to a high experimental error. Thus, as $\mathrm{dbh}$ and volume presented very high genetic and phenotypic correlations (0.92), and dbh is an easily measurable trait, the selection can be based on this specific trait, resulting in indirect gains in volume. Moreover, the correlations among three forest traits present values close to those found in the literature (Table 5) as well as the same tendency, with higher correlations between $\mathrm{dbh}$ and volume. SAMPAIO (2000), working with a multi-effect index in $P$. caribaea hondurensis suggested to use $\mathrm{dbh}$ for indirect selection in volume. According to the author, the selection of plus trees, aiming to maximize the genetic gains in volume, must be based on the dbh because of the high additive genetic correlation coefficients and the low standard deviation between of this trait and volume. Other studies with Pinus sp. support the same conclusion (SEBBENN et al., 1994; ZHENG et al., 1994; Missio et al., 2004).

The expected genetic gains from selection were high for all studied traits, being $8.92 \%$ for height and $37.56 \%$ for volume. It is important to pinpoint that these expected gains are predictions for trees with 14 years of age, growing in sites as the same characteristics of the Selvíria site and originated from the mating among the selected trees here. 
Table 4. Estimates of genetic correlations $\left(r_{g}\right)$ and phenotypic $\left(r_{f}\right)$ between height, dbh, and volume for some coniferous species

\begin{tabular}{|c|c|c|c|c|}
\hline Traits & Species & $\hat{r}_{g}$ & $\hat{r}_{f}$ & Authors \\
\hline \multirow[t]{8}{*}{ Height $x \mathrm{dbh}$} & P. echinata & 0.87 & - & TAUER and McNew (1985) \\
\hline & P. patula & 0.46 & 0.42 & BARNES et al. (1992) \\
\hline & P. oоcarpa & 0.43 a 0.86 & & SAMPAIO et al. (2000) \\
\hline & P. radiata & 0.87 & 0.56 & DEAN et al. (1983) \\
\hline & P. radiata & 0.72 & 0.71 & CotTerill and Zed (1980) \\
\hline & P. taeda & 0.81 & 0.78 & SHELbOURNE et al. (1969) \\
\hline & P. taeda & 0.87 & 0.74 & MAtZIRIS and Zobel (1973) \\
\hline & P. menziesii & 0.75 & 0.81 & STCLAIR (1994) \\
\hline \multirow[t]{2}{*}{ Average } & & 0.74 & 0.67 & \\
\hline & P.caribaea hondurensis & 0.79 & 0.66 & Present Work \\
\hline \multirow[t]{7}{*}{ Height $x$ Vol } & P. echinata & 0.94 & - & TAUER and McNew (1985) \\
\hline & P. patula & 0.94 & 0.60 & BARNES et al. (1992) \\
\hline & P. oоcarpa & 0.53 a 0.92 & - & SAMPAIO et al. (2000) \\
\hline & P. radiata & 0.93 & 0.76 & DEAN et al. (1983) \\
\hline & P. taeda & 0.88 & 0.81 & SHELBOURne et al. (1969) \\
\hline & P. menziesii & 0.85 & 0.90 & STCLAIR (1994) \\
\hline & P. taeda & - & 0.84 & MATZIRIS and ZOBEL (1973) \\
\hline \multirow[t]{2}{*}{ Average } & & 0.86 & 0.78 & \\
\hline & P.caribaea hondurensis & 0.85 & 0.72 & Present Work \\
\hline \multirow[t]{4}{*}{$\mathrm{dbh} \times \mathrm{Vol}$} & P. oocarpa & 0.92 a 0.99 & - & SAMPAIO et al. (2000) \\
\hline & Pseudotsuga menziesii & 0.97 & 0.99 & StCLAIR (1994) \\
\hline & P. patula & 0.81 & 0.91 & BARNES et al. (1992) \\
\hline & P. taeda & 1.00 & 0.90 & MATZIRIS and ZOBEL (1973) \\
\hline \multirow[t]{2}{*}{ Average } & & 0.94 & 0.93 & \\
\hline & P.caribaea hondurensis & 0.92 & 0.92 & Present Work \\
\hline
\end{tabular}

Table 5. Estimates of absolute $\left(G_{S}\right)$ and relative gains ( $\left.\ddot{A} G\right)$ for selection of $15 \%$ of families and $10 \%$ of trees within families for height, dbh, and volume of P. caribaea var. hondurensis at 14 years of age established at Selvíria, State of Mato Grosso do Sul, Brazil

\begin{tabular}{|c|c|c|c|c|c|c|}
\hline \multirow{3}{*}{ Trait } & \multicolumn{6}{|c|}{ Gains of selection } \\
\hline & \multicolumn{2}{|c|}{ Among families } & \multicolumn{2}{|c|}{ Within families } & \multicolumn{2}{|c|}{ Total } \\
\hline & $\mathrm{G}_{\mathrm{S}}$ & $\triangle G$ & $\mathrm{GS}_{\mathrm{S}}$ & $\triangle \mathrm{G}$ & $\mathrm{G}_{\mathrm{S}}$ & $\triangle G$ \\
\hline & & & & & & \\
\hline Height (m) & 0.72 & 3.10 & 1.35 & 5.82 & 2.07 & 8.92 \\
\hline $\mathrm{dbh}(\mathrm{cm})$ & 1.21 & 4.82 & 1.50 & 5.99 & 2.71 & 10.82 \\
\hline Volume $\left(\mathrm{m}^{3}\right)$ & 0.11 & 14.83 & 0.17 & 22.73 & 0.28 & 37.56 \\
\hline
\end{tabular}




\section{ACKNOWLEDGEMENTS}

This research was supported by Fundação de Amparo à Pesquisa do Estado de São Paulo - FAPESP (Project 04/09508-8). We are grateful to Sanjna Shah and Dr. Fábio Tebaldi Silveira Nogueira by English corrections in this article.

\section{REFERENCES}

BALLONI, E.A.;JACOB, W.S.; SIMÕES, J.W. Resultados parciais de experimentação desenvolvidos pelo setor de implantação florestal com diferentes espécies de Pinus. Boletim Informativo IPEF, v. 6, n.18, p.75-87, 1978.

BARRICHELO, L.E.G.; KAGEYAMA, P.Y.; SPELTZ, R.M.; BONISH, H.J.; BRITO, J.O.; FERREIRA, M. Estudos de procedências de Pinus taeda visando seu aproveitamento industrial. Boletim Informativo IPEF, v. 6, n.18, p.1-14, 1978.

BYRNE, M.; MARQUEZ-GARCIA, M.I.;UREN, T.;SMITH, D.S.; MORAN, G.F. Conservation and genetic diversity of microsatellite loci in the genus Eucalyptus. Australian Journal of Botany, v. 44, p.331-41, 1996.

CAMCORE. CAMCORE (Central America \& Mexico Coniferous Resources Cooperative) Annual Report. Departament of Forestry, North Caroline State University, Raleigh, North Caroline, USA, 1996.

COCHRAN, W.G.; COX, G.M. Diseños experimentales. Cidade del México 7.ed. Editorial Trillas, 1981. 661p.

DOYLE, J.J.; DOYLE, J.L. A rapid DNA isolation procedure for small quantities of fresh leaf tissue. Phytochem Bull, n.19, p.11-15, 1987.

ECHT, C.S.; BURNS, R. SSR derived from Pinus taeda 1999. ESTs.http://dendrome.ucdavis.edu/Data/ssr-est.html <acesso em 09/04/2003>

ECHT, C.S.; MAY-MARQUARDT, P.; HSEIH, M.; ZAHORCHAK, R. Characterization of microsatellite markers in eastern white pine. Genome, v. 39, p.1102-1108, 1996.

ECHT, C.S.; VENDRAMIN, G.G.; NELSON, C.D.; MARQUARDT, P. Microsatellite DNA as shared genetic markers among conifer species. Canadian Journal of Forest Research, v. 29, p.365-371, 1999.

ELSIK, C.G.; WILLIAMS, C.G. Low-copy microsatellite recovery from a conifer genome. Theoretical and Applied Genetics, v. 103. p.1189-1195p. 2001.

FALCONER, D.S. Introdução genética quantitativa. Viçosa: Imprensa Universitária, 1981. 279p.

FERREIRA, M.E.; GRATTAPAGLIA, D. Introdução ao uso de marcadores moleculares em analise genética. Brasília-DF: EMBRAPA-CENARGEN, 1998. 220p.
FREITAS, M.L.M.; MORAES, E.; ZANATTO, A.C.S.; LEMOS, S.V.; FERNANDES, A.C.; SEBBENN, A.M. Teste de procedências de Pinus caribaea var. hondurensis aos 32 anos em Bebedouro-SP. Rev. do Inst. Flor, v. 17, n. 1, p.17-23, 2005.

FURLAN, R.A.; MORI, E.S.; TAMBARUSSI, E.V.; MORAES, C.B.; JESUS, F.A; ZIMBACK, L. Estrutura genética de populações de melhoramento de Pinus caribaea var. hondurensis por meio de marcadores microssatélites. Bragantia, v. 66, n.4, p.553-563, 2007.

GRATTAPAGLIA, D.; SEDEROFF, R.R. Genetic linkage maps of Eucalyptus grandis and E. urophylla using a pseudo-testcross mapping strategy and RAPD markers. Genetics, v.137, p.11211137, 1994.

HICKS, M.; ADAMS, D.; O'KEEFE, S.; MACDONALD, E.; HODGETTS, R. The development of RAPD and microsatellite markers in lodgepole pine (Pinus contorta var. latifolia). Genome, v. 41, p.797-805, 1998.

HODGE, G.R.; DVORAK, W.S. Genetic parameters and provenenance variation of Pinus caribaea var. hondurensis in 48 international trials. Canadian Journal of Forest Research, v. 31, n.3, p.496-511, 2001.

KOSTIA, S.; VARVIO, S.; VAKKARI, P.; PULKKINEN, P. Microsatellite sequeces in a conifer, Pinus sylvestris. Génome, v. 38, p.1244-1248, 1995.

LIMA, R.T. Comportamento de espécies/procedências tropicais do gênero Pinus em Felixlândia, MG - BRASILRegião de cerrados 1 - Pinus caribaea var. hondurensis e Pinus oocarpa. Revista Árvore, v. 14, n.1, p.16-25, 1990.

MATHESON, A.C.; BELL, J.C.; BARNES, R.D. Breeding systems and genetic structure in some Central American pine populations. Silvae Genetica, v. 38, p.107-112, 1989.

MIRANDA FILHO, J.B. Princípios de experimentação e analise estatística. In: PATERNIANI, E. (Ed.) Melhoramento de milho no Brasil. Piracicaba: Fundação Cargill, 1978. p. 620-50.

MISSIO, R.F.; CAMBUIM, J.; MORAES, M.L.T.; PAULA, R.C. Seleção simultânea de caracteres em progênies de Pinus caribaea Morelet var. bahamensis. Scientia Forestalis, n. 66, p.161-166, 2004.

NICOLIELO, N. Comportamento de procedências de Pinus caribaea Morelet na região de Agudos-SP. 1984. 97p. Dissertação (Mestrado-Agronomia: Genética e Melhoramento de Plantas) Escola Superior de Agricultura "Luiz de Queiroz", Universidade de São Paulo, Piracicaba.

PERRY, J.P. The pines of Mexico and Central America. Timber Press, OR. 1991.

RESENDE, M.D.V. Genética biométrica e estatística no melhoramento de plantas perenes. Brasília-DF: EMBRAPA, 2001. $917 \mathrm{p}$.

RICHARDSON, D.M. Ecology and Biogeography of Pinus. Cambridge, England, University Press. ISBN 0521-55176-5, 1998. 
RITLAND, K. Correlated matings in the partial selfer Mimulus guttatus. Evolution, v. 43, n. 4, p.848-859, 1989.

RITLAND, K. Extensions of models for the estimation of mating systems using $n$ independent loci. Heredity, v. 88 , p.221-228, 2002.

RITLAND, K.; JAIN, S.K. A model for the estimation of outcrossing rate and gene frequencies using $\mathrm{n}$ independent loci. Heredity, v. 47, p.35-52, 1981.

S.A.S. INSTITUTE INC. SAS procedures guide. Version 8 (TSMO).Cary,1999. 454 p.

SAMPAIO, P.T.B.; RESENDE, M.D.V.; ARAÚJO, A.J. Estimativas de parâmetros genéticos e métodos de seleção para o melhoramento genético de Pinus caribaea hondurensis. Revista Agropecuária Brasileira, v.7, n.11, p.2243-2253, 2000.

SEBBENN, A.M. Número de árvores matrizes e conceitos genéticos na coleta de sementes para reflorestamentos com espécies nativas. Revista do Instituto Florestal, v. 14, n. 2, p.115-132, 2002.

SEBBENN, A.M. Tamanho amostral para conservação $e x$ situ de espécies arbóreas com sistema misto de reprodução. Revista do Instituto Florestal, v. 15, n. 2, p. 109-124, 2003.

SEBBENN, A.M.; PIRES, C.L.S.; CUSTÓDIO FILHO, A.; ROSA, P.R.F. Variação genética em progênies de meiosirmãos de Pinus caribaea Mor. var. bahamensis Bar. et. Gol. na Região de Bebedouro, SP. Revista do Instituto Florestal, v. 6, p. 63-73. 1994.

SEBBENN, A.M.; PIRES, C.L.S.; SALDANHA, H.X.; ZANATTO, A.C.S. Teste de progênies de polinização livre de Pinus tecunumanii (Eq. Et Per.) Styles de San Rafael Del Norte, na região de São Simão, SP. Revista do Instituto Florestal, v. 7, n.2, p.241-252, 1995.

SEBBENN, A.M.; KAGEYAMA, P.Y.; ZANATTO, A.C.S. Estimativas de ganhos genéticos na seleção em populações de Cariniana legalis (Mart.) O. Ktze, incorporando informações do sistema misto de reprodução. Revista do Instituto Florestal, v. 14, p. $65-77,2002$.

SMITH, J.S.C.; DEVEY, M.E. Occurrence and inheritance of microsattelites in Pinus radiata. Genome, v.37, p.977983, 1994.

VENCOVSKY, R.; BARRIGA, P. Genética biométrica no fitomelhoramento. Ribeirão Preto: Sociedade Brasileira de Genética, 1992. 486p.

WILLIAMS, C.G.; HAMRICK, J.L. Niveles de diversidad genetica en un programa de generación avanzada de Pinus taeda L. medidos con el uso de marcadores moleculares. Forest Genetics Resource Information, v.23, p.50-56, 1995.

ZHENG, Y.; ENNOS, R.; WANG, H. Provenance variation and genetic parameters in a trial of Pinus caribaea var. bahamensis Barr. and Golf. Forest Genetics, v. 1, n. 3, p.167$174,1994$. 